\title{
Effect of three weeks' treatment with budesonide on in vitro contractile and relaxant airway effects in the rat
}

\author{
B GUSTAFSSON, C G A PERSSON \\ From the Pharmacological Laboratory, AB Draco, and the Department of Clinical Pharmacology, University \\ Hospital, Lund, Sweden
}

\begin{abstract}
An investigation was carried out to determine whether the sensitivity of rat trachealsmooth muscle to contractile and relaxant drugs was affected by three weeks' treatment with subcutaneous budesonide before death. Budesonide treatment was associated with a lower thymus윽 weight and a smaller gain in body weight than in control animals. There was, however, no differencein the carbachol concentration-response curves or maximum responses to carbachol of trachealo smooth muscle from control and budesonide treated rats. Isometric and isotonic recordings agreed in these respects. Glucocorticoid treatment did not increase the sensitivity of tracheal smooth muscle to $₹$ the relaxant drugs terbutaline and enprofylline; if anything there was a tendency for terbutaline and $\vec{\oplus}$ enprofylline to be less potent after budesonide treatment. The data suggest that in vivo effects of 0 glucocorticoids on airway responsiveness to bronchodilating and bronchoconstricting drugs are unlikely to be due to a direct effect on bronchial smooth muscle.
\end{abstract}

\section{Introduction}

Treatment with inhaled glucocorticoids for a few weeks has been shown to reduce non-specific airway hyperreactivity in patients with asthma. ${ }^{12}$ Although airway hyperreactivity is thought to be due to inflammation it is measured as sensitivity to inhaled bronchoconstrictors such as histamine and muscarinic agonists. ${ }^{3}$ There appears to be no information on the effects of prolonged treatment with glucocorticoids on tracheobronchial smooth muscle or on non-specific reactivity in airways from healthy subjects. Such experiments are needed to exclude the possibility that glucocorticoids exert a direct effect on airway smooth muscle in addition to their anti-inflammatory actions, thereby reducing the responsiveness of smooth muscle to bronchoconstricting agents. Glucocorticoids may have a direct effect on smooth muscle. It has been claimed from in vitro studies that glucocorticoids make airway smooth muscle more responsive to both $\beta$ receptor agonists and xanthines. ${ }^{46}$ In asthmatic patients with a poor acute bronchodilator response to $\beta_{2}$ receptor agonists airway responsiveness to $\beta$ agonists can be increased with glucocorticoid treatment. ${ }^{4}$

Address for reprint requests: Dr Carl Persson, Pharmacological Laboratory, AB Draco, Box 34, S-221 00 Lund, Sweden.

Accepted 26 September 1988
We have examined the effects of three weeks' in vivo treatment with budesonide on rat tracheal smooth muscle responsiveness to a muscarinic agent (carbachol), a $\beta_{2}$ adrenoceptor agonist (terbutaline), and axanthine without adenosine blocking activityo (enprofylline). The effects were evaluated in vitro by isometric and isotonic recording techniques.

\section{Methods}

We used male Sprague-Dawley rats weighing abou $\mathscr{C}$ $200 \mathrm{~g}$ at the start of the study. The rats were identified individually by colour code markings. Three rats wereo housed in each cage. Food and water were unrestricted.

Micronised budesonide was dissolved in $99 \%$ eth anol at a ratio of $2 \mathrm{mg}$ budesonide in $1 \mathrm{ml}$ ethanol, $100 \mathrm{ml} 0.9 \%$ sodium chloride was added to this solution while it was being stirred. Sodium chloridew was added to ethanol in the same way for the controb solution. Fresh solutions were prepared every othes day. Solutions were stored at $5^{\circ} \mathrm{C}$ and protected fron light.

Each rat received two subcutaneous injections of $20 \mu \mathrm{g}$ budesonide $/ \mathrm{kg}$ or control solution daily at $\overrightarrow{\mathrm{D}}$ constant volume dosage of $1 \mathrm{ml} / \mathrm{kg}$, the volum administered being based on body weight at the time्ष of administration. Seven injection sites were used in numerical order in each rat, so that a new site was used 
every day of the week. Fifteen animals were treated with budesonide and 15 with control solution.

After three weeks of treatment the rats were weighed and then killed by a blow on the head. This was done about 14 hours after the last injection. The thymus was dissected out and weighed. The trachea was carefully trimmed of excess tissue and cut into pieces containing two adjoining cartilage rings, which were weighed. Open tracheal rings were prepared by cutting through the cartilage opposite the muscle. The open ring was mounted in a jacketed $25 \mathrm{ml}$ organ bath, controlled at a temperature of $37^{\circ} \mathrm{C}$, containing Krebs' solution (composition (mM): $\mathrm{NaCl} 118 \cdot 0, \mathrm{KCl} 4 \cdot 6, \mathrm{CaCl}_{2} 2 \cdot 5$, $\mathrm{MgSO}_{4} 1 \cdot 15, \mathrm{NaHCO}_{3} 24 \cdot 9, \mathrm{KH}_{2} \mathrm{PO}_{4} 1 \cdot 15$, glucose 5.5, with a $\mathrm{pH}$ of $7 \cdot 4$, aerated with $5 \%$ carbon dioxide in oxygen). Two tracheal rings were cut from each trachea, one to be used for isometric and the other for isotonic measurements. Changes in muscle tension were recorded isometrically by means of strain gauge transducers. Changes in muscle length were recorded isotonically by means of Harvard isotonic transducers, which convert rotary motion into an electrical signal. All measurements were recorded on a Grass polygraph. The initial mounting tension and load were adjusted to about $0.5 \mathrm{~g}$ for isometric and isotonic recordings respectively. Preparations were allowed to stabilise for $\mathbf{3 0}$ minutes with repeated washings.

Drugs were added by injection into the organ baths. Carbachol $4.4 \times 10^{-7} \mathrm{M}$ was always added first to each trachea for standardisation of contraction. The cumulative concentration-response relationship for Carbachol was then determined by increasing stepwise the concentration in the bath (range $10^{-8}-10^{-3} \mathrm{M}$ ) until no further effect was achieved by two consecutive concentrations. The trachea was then washed and after it had returned to baseline it was contracted with

Table 1 Mean (SEM) responses of rat tracheal rings measured isotonically (IT) and isometrically (IM)

\begin{tabular}{|c|c|c|c|}
\hline & $n$ & $\begin{array}{l}-\log E C_{50} \\
(\mathrm{~mol} / \mathrm{l})\end{array}$ & $\begin{array}{l}\text { Maximum } \\
\text { induced } \\
\text { changest }\end{array}$ \\
\hline $\begin{array}{l}\text { CONTROL } \\
\text { Carbachol IT } \\
\text { IM } \\
\text { Enprofylline IT } \\
\text { IM } \\
\text { Terbutaline IT } \\
\text { IM }\end{array}$ & $\begin{array}{r}15 \\
15 \\
7 \\
7 \\
7 \\
8\end{array}$ & $\begin{array}{l}6.28(0.05) \\
6.49(0.05) \\
3.92(0.03) \\
3.98(0.10) \\
3.62(0.11) \\
4.04(0.17)\end{array}$ & $\begin{array}{l}0.9 \pm 0.1 \\
0.4 \pm 0.1 \\
0.3 \pm 0.1 \\
0.2 \pm 0.1 \\
0.4 \pm 0.1 \\
0.3 \pm 0.1\end{array}$ \\
\hline $\begin{array}{l}\text { BUDESONIDE TREA TED } \\
\text { Carbachol IT } \\
\text { IM } \\
\text { Enprofylline IT } \\
\text { IM } \\
\text { Terbutaline IT } \\
\text { IM }\end{array}$ & $\begin{array}{r}14 \\
14 \\
6 \\
6 \\
4 \\
5\end{array}$ & $\begin{array}{l}6.28(0.09) \\
6.51(0.08) \\
3.72\left((0.06)^{*}\right. \\
3.82(0.08) \\
3.45(0.21) \\
3.53(0.09)^{*}\end{array}$ & $\begin{array}{l}0.7 \pm 0.1 \\
0.6 \pm 0.1 \\
0.3 \pm 0.1 \\
0.3 \pm 0.1 \\
0.3 \pm 0.1 \\
0.5 \pm 0.1\end{array}$ \\
\hline
\end{tabular}

*Significantly different from controls: $\mathrm{p}<\mathbf{0 . 0 5}$.

tIn millimetres for isotonic and grams for isometric recordings. $\mathrm{EC}_{50}$ - concentration producing $50 \%$ of the maximum effect.
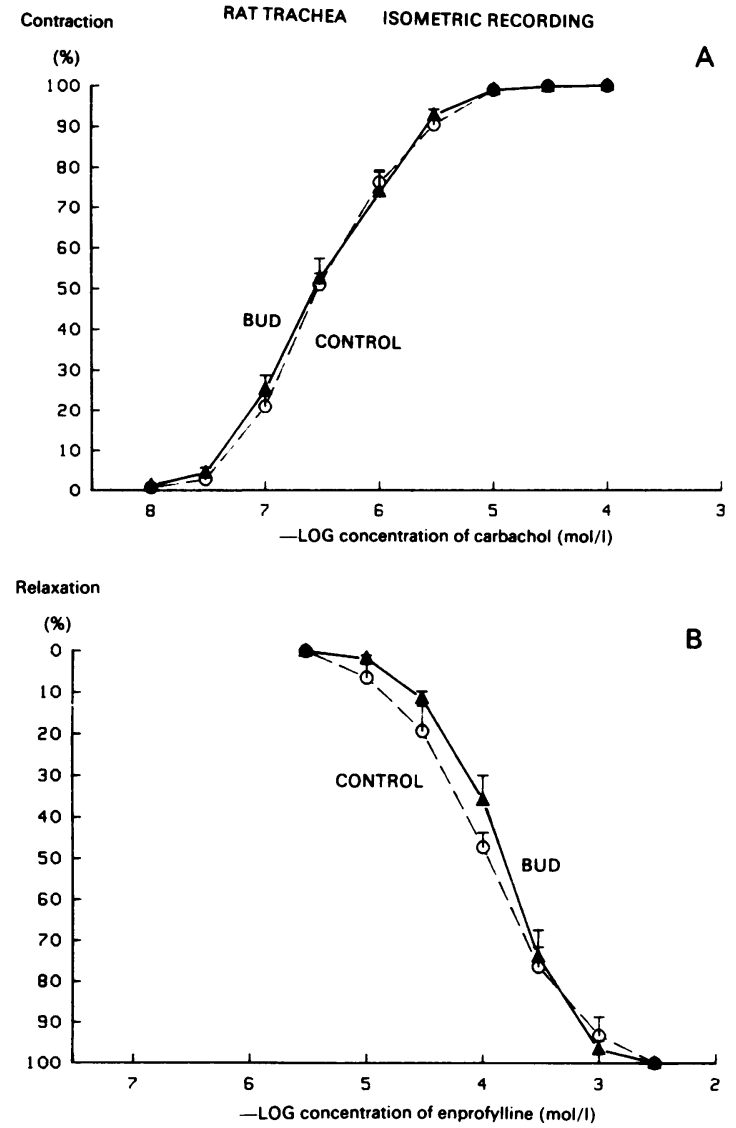

Relaxation

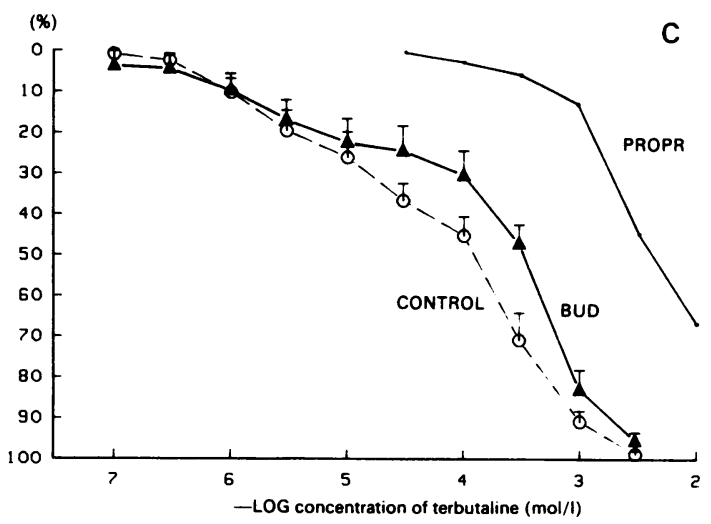

Concentration-response curves, indicating means with standard errors, for Carbachol ( $A$ ), enprofylline (B) and terbutaline $(C)$ in the absence and presence of propranolol (PROPR) $10^{-7} \mathrm{M}$ in budesonide treated $(\triangle, B U D)$ and vehicle treated rats (O,CONTROL). Responses are expressed as percentages of the maximum contraction obtained with Carbachol $(A)$ and as percentages of the maximum relaxation obtained with enprofylline $(B, C)$. 
carbachol $4.4 \times 10^{-7} \mathrm{M}$, corresponding to $70 \%$ of the maximum effect of carbachol. Terbutaline or enprofylline was then added in increasing doses $\left(10^{-7}-3 \times 10^{-3} \mathrm{M}\right)$ to achieve its own maximal effect. Enprofylline $3 \times 10^{-3} \mathrm{M}$ was always added on top of the terbutaline evaluations to give a standard maximal relaxation. Tracheas from three budesonide pretreated animals and three control animals were tested in this way each day. In separate experiments propranolol $10^{-7} \mathrm{M}$ was added 20 minutes before evaluation of the terbutaline concentration-response relationship.

The drugs used were carbamylcholine chloride (Carbachol; Sigma), enprofylline (Draco), terbutaline sulphate (Draco), budesonide (Draco), propranolol chloride (Hässle). All drugs other than budesonide were diluted with a $0.9 \%$ sodium chloride solution.

\section{ANAL YSES}

Concentration-response curves were expressed as percentages of the maximal response seen. Data are presented as means and standard errors. Linear regression analysis was performed at three or four points of measurement on the linear part of the dose-response curves. From the equation of each regression line we obtained an $\mathrm{EC}_{50}$ value (the concentration producing $50 \%$ of the maximum effect). $\mathrm{EC}_{50}$ values were $\log$ transformed for analyses and geometric mean values obtained. The difference between mean values was examined with Student's $t$ test for unpaired observations.

\section{Results}

Tracheas from both control and budesonide treated rats were stable and once the initial tone (length) had been set there was little spontaneous change in baseline recordings. There was no difference between control and budesonide treated rats in the response to carbachol $\left(\mathrm{EC}_{50}\right.$ and maximum effect, isometric and isotonic recordings: table 1 , fig A), or in the potency of terbutaline and enprofylline in causing relaxation (table 1, figs B, C). The geometric mean $\mathrm{EC}_{50}$ values for terbutaline and enprofylline tended to be larger in preparations from budesonide treated rats than con-

Table 2 Mean (SD) organ weights expressed as percentages of body weight

\begin{tabular}{llll}
\hline & $\begin{array}{l}\text { Body } \\
\text { weight }(g)\end{array}$ & $\begin{array}{l}\text { Tracheal rings } \\
(\times 1000)\end{array}$ & $\begin{array}{l}\text { Thymus } \\
(\times 1000)\end{array}$ \\
\hline $\begin{array}{c}\text { Control } \\
(\mathrm{n}=15) \\
\begin{array}{c}\text { Budesonide } \\
\text { treated } \\
(\mathrm{n}=15)\end{array}\end{array}$ & $342.1(17.4) 1.75 \times 10^{-2}\left(0.29 \times 10^{-2}\right)$ & $2.59(0.30)$ \\
\hline
\end{tabular}

*Significantly different from controls: $p<0.001$. trol rats and the difference was significant for the isotonic recording with enprofylline and the isometric recording with terbutaline (table 1). The terbutaline concentration-response curves had a biphasic shape, $\overline{(\bar{D}}$ seen most clearly in the isometric recordings of budesonide treated animals (fig C). Both the initial and the steeper part of the terbutaline dose-response curve ${ }^{\infty}$ were shifted to the right by $10^{-7} \mathrm{M}$ propranolol (fig C). $\vec{\circ}$ There was no significant difference in the maximum responses of enprofylline and terbutaline on tracheas obtained from control and budesonide treated animals (table $1 ; \mathrm{p}>0.05$ ).

The increase in body weight was less in budesonide $\stackrel{+}{+}$ treated than control animals $(39 \% v 68 \% ; p<0.001)$ The weight of the thymus (expressed as percentage of body weight) was lower in the budesonide treated? animals than in control animals $(p<0.001)$. The weights of the tracheal rings showed no differencen between controls and treated rats (table 2).

\section{Discussion}

Since glucocorticoids were first used in the treatment of asthma an effect of these drugs on airway smooth muscle has been postulated. According to Ellul Micallef, ${ }^{4}$ it was Lefcoe $^{7}$ who first reported thato hydrocortisone relaxed guinea pig isolated tracheas: Although this effect was repeated by others it was probably not a true glucocorticoid action but due to $\vec{F}$ constituents of the vehicle. ${ }^{8}$ Recent studies have 3 focused on a glucocorticoid induced enhancement of $\beta \supset$ receptor mediated airway smooth muscle relaxation? This is induced rapidly in vitro.

This action on $\beta$ receptor responsiveness may not, however, be related to glucocorticoid anti-inflam matory effects as it is not produced by all glucocor:음 ticoids, and is produced with the readily catabolise catecholamines, such as isoprenaline, but not with theo non-catecholamines, such as terbutaline, salbutamol and fenoterol. ${ }^{910}$ Rat airway smooth muscle is less sensitive to $\beta$ receptor stimulation." In the presents study the poor sensitivity was reduced rather thar? improved by prolonged glucocorticoid treatment. The suggestion that glucocorticoids increase airway relax ation by xanthines ${ }^{6}$ has not been confirmed and is contradicted by the present data with enprofylline which is a more potent airway anti-inflammatory and relaxant xanthine than theophylline. ${ }^{12}$ In general, there was agreement between the isotonic and isometric recordings for the measurement of the potencies of the? contractile and relaxant drugs and their concen- 0 tration-response curves. This finding agrees witho observations in human small airway preparations in vitro. ${ }^{13}$

The present study showed that treatment of rats for three weeks with budesonide, a potent glucocorticoid 
in animal systems that is effective in asthma, ${ }^{1214}$ did not in any respect reduce the ability of a muscarinic agonist to contract isolated airway smooth muscle. The dose of budesonide was effective, to judge by the reduced gain in body weight and the reduced weight of the thymus. These data suggest that the reduced nonspecific airway reactivity seen in vivo after treatment with glucocorticoid is unlikely to be due to a direct effect of glucocorticoids on airway smooth muscle.

\section{References}

1 Kraan J, Koetu GH, Mark TW, Sluiter HJ, de Vries K. Changes in bronchial hyperreactivity induced by four weeks of treatment with antiasthmatic drugs in patients with allergic asthma. A comparison between budesonide and terbutaline. J Allergy Clin Immunol 1985; 76:628-36.

2 Kerrebijn KF, van Essen-Zandoiet EEM, Neijens HJ. Effect of long-term treatment with inhaled corticosteroids and beta-agonists on the bronchial responsiveness in children with asthma. J Allergy Clin Immunol 1987;79:653-9.

3 Hargreave FE, Woolcock AJ, eds. Airway responsiveness: measurement and interpretation. Canada: Astra Pharmaceuticals Canada, 1985.

4 Ellul-Micallef R. Pharmacokinetics and pharmacodynamics of glucocorticosteroids. In: Jenne JW, Murphy S, eds. Drug therapy for asthma. (Lenfant C, ed. Lung biology in health and disease. Vol 31.) New York: Dekker, 1987:463-516.

5 Toogood JH. Corticosteroids. In: Jenne JW, Murphy S, eds. Drug therapy for asthma. (Lenfant C, ed. Lung biology in health and disease. Vol 31.) New York: Dekker, 1987:719-59.
6 Kolbeck RC, Downing DL, Harrison GN, Chaudhary BA, Speir WA. Potentiation of the bronchodilator response to theophylline and isoproterenol: in vitro studies with hydrocortisone. Am Rev Respir Dis 1979; 119:137.

7 Lefcoe NM. The effect of hydrocortisone hemisuccinate on the tracheal smooth muscle of the guinea pig and cat. J Allergy 1956;27:352-8.

8 Geddes BA, Lefcoe NM. Respiratory smooth muscle relaxing effect of commercial steroid preparations. Am Rev Respir Dis 1973;107:395-9.

9 Foster PS, Goldie RG, Paterson JW. Effect of steroids on $\beta$-adrenoreceptor-mediated relaxation of pig bronchus. Br J Pharmacol 1983;78:441-5.

10 Persson CGA, Andersson PT, Gustafsson B. Budesonide and airway smooth muscle tone. Budesonide reduces sensitivity to antigen but does not alter baseline tone or responsiveness to carbachol, terbutaline, or enprofylline in IgE-sensitized guinea-pig tracheae. Int Arch Allergy Appl Immunol (in press).

11 Persson CGA, Karlsson J-A. In vitro responses to bronchodilator drugs. In: Jenne JW, Murphy S, eds. Drug therapy for asthma. (Lenfant C, ed. Lung biology in health and disease. Vol 31.) New York: Dekker, 1987: 129-76.

12 Persson CGA. Development of safer xanthine drugs for treatment of obstructive airways disease. J Allergy Clin Immunol 1986;78:817-24.

13 De Jongste JC, Mons H, van Strik R, Bonta IL, Kerrebijn $\mathrm{KF}$. Comparison of isometric and isotonic responses of human small airway smooth muscle in vitro. $J$ Pharmacol Methods 1987;17:165-71.

14 Brattsand R, Andersson PT, Edsbäcker S, Ryrfeldt $\AA$. Development of glucocorticosteroids with lung selectivity. In: Ellul-Micallef R, Lam WK, Toogood JH, eds. Advances in the use of inhaled glucocorticosteroids. Amsterdam: Excerpta Medica, 1987:68-78. 